\title{
Politics ANd Religion in Graeco-Roman EgyPT
}

\author{
Heba Magdy \\ Assistant Professor, Guiding Department \\ Faculty of Tourism and Hotels, Alexandria University
}

\begin{abstract}
Religion and politics always have been interconnected. Throughout the ages, the rulers used the religion to achieve some political goals. This started in the Pharaonic period, and was later used by the Ptolemies and the Roman Emperors to stabilize their rule. Actually, this method proved a success as the Ptolemaic kingdom lasted for nearly 300 years, and the Roman rule continued for another 600 years. Many methods were used to persuade the Egyptians such as: respecting the sacred animals, establishing temples for the Egyptian gods, the veneration of the kings and the Emperors.
\end{abstract}

Keywords: Religion - Politics - sacred animals - miracles - priests - revolts.

\section{Introduction}

Religion and politics always have been interconnected. This can be certainly recognized in our modern times in what is called the Political Islam, in which certain brotherhoods announced wars based on religious claims. This wasn't the first time to see such wars fought on religious claims, as earlier in time there were the crusades. The crusades were a series of religious and political war fought between 1096 and 1292 for control of the holy Land. Pope Urban II initiated the First Crusade. The Christians thought that the crusades are the path to salvation for those who participated. The church promoted taking the cross and going on to the holy Land as a demonstration of Christian love and devotion to God. For a long time, there was a powerful bond between the church and the state since the Pope had the ultimate authority over the church and over the state. The ruler of the state had to be crowned by the priest before starting his reign. It was in the medieval period that attempts were made to separate the church from the state. The researcher here wants to investigate the existence of this interconnection between the religion and politics in ancient Egypt and revealing its forms precisely during the Graeco-Roman era. ${ }^{1}$

\section{During the Pharaonic period}

Politics and Religion in ancient Egypt are two sides of the same coin. During the Pre-dynastic period, each region in Egypt had its own local god. These dispersed religious regions were due to the political independence of each. When the economical and the political power of some regions rose, their local gods began to take more importance. This leads to the diminution of the other local deities and submit them to completely shade. When these separated regions were united under two main kingdoms (Upper and Lower Egypt), two main deities gained the

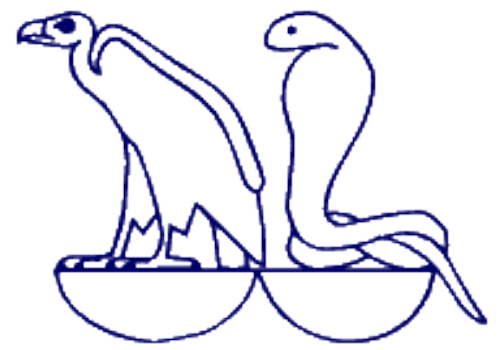

nbty name 
importance (Nekhbet and Wadjet). When these two kingdoms unified, the ancient Egyptian artist was keen on representing both deities in his work, even in the title of the king (the Nbty). The nbty name was written after the vulture and cobra, images of the two goddesses of Upper and Lower Egypt. ${ }^{2}$

At that time, there was a necessity of having a main dominant deity in the Whole land of Egypt. This main deity changed throughout the ancient Egyptian history, according to the origin of the ruling king. For example, Horus was the main god during the rule of the Thinite Kings. ${ }^{3}$ When the capital was relocated to Memphis in the third dynasty, the official state god became Ptah of Memphis. ${ }^{4}$ During the Middle Kingdom the main god became Montu, god of war and the local god of Arment. ${ }^{5}$ This could be related to the political change that occurred at that time when the rulers of the $11^{\text {th }}$ dynasty were from Arment. When the rule of Egypt was seized by a Theban man during the $12^{\text {th }}$ dynasty, the god of Thebes (Amun) became the main god of the country at that time. Soon the capital of Egypt was transferred to El-Fayoum; therefore, God Sobek gained all the interest. However, Amun continued to be entitled "the master of the thrones of the two lands". The importance of Amun rose after the victory that occurred during the $18^{\text {th }}$ dynasty over the Hyksos. Meanwhile, God Amon was incorporated into God Re and called "Amun-Re". God Amun-Re kept his importance till the end of the Pharaonic period, except for the reign of Amenophis IV when the main god was "Aten". 6

Thus, we can recognize from what was mentioned before that the political change affected the religion in ancient Egypt. It is worth mentioning also that the Pharaohs stabilized their rule by claiming religious power and support. No one can reject the orders of the kings if he has a lineage with the god. From the early period, the Pharaoh was considered as being the god Horus on earth. With his death, the Pharaoh acquired the full status of a god and was associated with the dead Osiris ${ }^{7}$.

Some kings claimed that they were selected from the god to rule the country in an oracular dream. Thutmosis III claimed that he was chosen to rule Egypt during the religious procession of god Amun at Karnak, when the statue of the god stopped in front of him and led him to the place reserved for the king. This story was inscribed on the walls of the temple. ${ }^{8}$ It seems that Tuthmosis III used this method, because of his struggle on the rule with Hatshepsut. The same can be found in the story of Tuthmosis IV that was recorded on what's called "The Dream Stela". According to the Story, Tuthmosis IV was out on a hunting trip in Giza. He stopped to rest under the head of the sphinx that was buried up to the neck in sand. The prince fell asleep and had a dream in which god Harmachis appeared to him, promising him to be the next king of Egypt if he cleared away the sand and restored the statue (sphinx). ${ }^{9}$ This stela was placed between the paws of the sphinx. Tuthmosis IV used this story to legitimize his rule because he wasn't the crown prince, as he had one or more older brothers which prior claim to Egypt's throne.

When the King wanted to gain more power, he claimed that he is the offspring of the god. This can be noticed in the story of the first kings of the fifth dynasty, which is mentioned in the last tale of the Westcar Papyrus. This papyrus was written in the Middle Kingdom but contains tales from the fourth dynasty. The last tale tells the story of a woman called Rededjet (wife of Re's priest) giving birth to her three sons. Upon the day of her children's birth, Ra orders Isis, Nephthys, Meskhenet, Heket and Khnum aid her. They disguise themselves as musicians and hurry to Reddedet's house to help her with the difficult birth. The three children are born, each described as strong and healthy, with limbs covered in gold and wearing headdresses of lapis Lazuli. ${ }^{10}$ The woman is identified as being the queen Khentkaus I, and the three children are the first three kings of the fifth dynasty (Userkaf, Sahure, Neferirkare). The story here confirms that these kings are the offspring of god Re. The 
archaeologists emphasized that those first three kings were descended from the kings of the fourth dynasty. ${ }^{11}$ It seems that the priests of Re at Heliopolis wanted to express their power and their role in the transition from the fourth to the fifth dynasty. That's why those kings invented what is called the sun-temple.

The same can be seen in the story of Queen Hatshepsut. Hatshepsut was the daughter of king Tuthmose I and the wife of Tuthmose II. After the death of her husband, Hatshepsut ruled Egypt despite of the presence of Tuthmose III (illegitimate son of Tuthmose II). While Tuthmose III became older, Hatshepsut's rule became insecure. To stabilize her rule, she claims a direct divine lineage. She claims that Amun is her father. On the walls of the northern colonnade on the second terrace at her temple at Deir El-Bahari, she inscribed a story detailing the night the Theban god Amon-Re approached Aahmes (her mother) in the form of Tuthmose I. The scene shows Amun sits facing Ahmose, while he extends a sign of life to the queen, symbolically impregnating her with the divine child. Next, they are raised to heaven by two goddesses, where the god Khnum shapes Hatshepsut and her royal Ka on the Potter's Wheel. The pregnant queen is then led to the birth room, where various gods record the divine birth. After the birth of Hatshepsut, her mother receives the congratulations of Amun, as her daughter Hatshepsut will be the ruling king of Egypt. ${ }^{12}$ Finally, it should be noted that Hatshepsut didn't need this divine support because she was a female, as other queens ruled Egypt in previous ages. She needed this divine support to face the power that Tuthmose III started to gain.

The same inscriptions that described Hatshepsut's divine birth were copied in Amenhotep III's temple at Karnak, also claiming Amenhotep III the son of god Amun. These inscriptions were inscribed in the birth room in the temple. The inscriptions say that Amun-Re visited Thutmose IV wife, the mother of Amenhotep III in her chamber, disguised as her husband Thutmose IV. He found her sleeping, but as soon as he entered her chamber, she was awakened by his divine aroma and then he revealed his true nature in front of her which was a divine god. After he made love to her, he told her that he had placed the ruler of Upper and Lower Egypt in her body. Words spoken by Amun-Re; "Amenhotep, ruler of Thebes, is the name of this child I have placed in your body...He shall exercise the beneficent kingship in this whole land...He shall rule the two lands like Ra forever.".13

Later, Ramses II claimed himself as a god during his lifetime, as his name began to be written without cartouches and after the formula of djed mdw that used to precede the names of the god. In his temple at Abu Simbel, the statue of Ramses II was placed inside the sanctuary of the temple beside the statues of Amun-Re and Ptah. This cult continued to flourish, even after the end of Egypt's Pharaonic period. $^{14}$

Because of the strong bond between the ancient Egyptians and their religion, all the foreign invaders who took control over the county tried to show a sympathy with the Egyptian religion to stabilize their rule. The Hyksos (Semitic people from southern Canaan), for example, who invaded Egypt in the $15^{\text {th }}$ dynasty, tried to show their respect to the Egyptian gods. They chose their main god to be god Seth. They adopted the Egyptian title, which suggests an acknowledgment of the Egyptian gods incorporated into these titles. On a door Jamb of Sakir-Har the inscription reads "Horus the possessor of the Wadjet and Nekhbet diadems. The golden Horus who establishes his boundary, Sakir-Har". A scribal palette of King Apophis uses the epithet "The living image of Re", "Son of Wadjet", "he whom Thoth instructed" and "The scribe of Re". Moreover, many Hyksos kings incorporated the god Re in their prenomes such as: Khayan Sewoserenre, Apophis Awoserre. ${ }^{15}$ However, it seems that the ancient Egyptians were certain that those kings didn't respect their gods, and probably all of this was 
propaganda to give an impression of their belief in the Egyptian pantheon. The ancient Egyptians probably reached to this conclusion from noticing that those kings ruled from Avaris, the centre of the Asiatic religion. The Kings are also named after deities of the Canaanite pantheon, such as: king Aper-Anati (after Anat), King Sakir-Har (after Harru). They didn't serve any god except for Seth. Therefore, the Egyptian sources claimed that the Hyksos ruled without Re. Thus, the Theban princes started the war against the Hyksos till they were expelled by Ahmose.

The same mistake was made by the Persians, who started their reign in Egypt in 523 BC by insulting the Egyptian religion. They killed the Apis bull and broke the statues of the gods into pieces. Herodotus mentioned in his book that Cambyses opened tombs and ridiculed the Egyptian gods in their temples. ${ }^{16}$

Cambyses committed many such mad acts against the Persians and his allies; he stayed at Memphis, and there opened ancient coffins and examined the dead bodies. Thus too he entered the temple of Hephaestus and jeered at the image there Also he entered the temple of the Cabeiri, into which no one may enter save the priest; the images here he even burnt, with bitter mockery. These also are like the images of Hephaestus, and are said to be his sons.

This led the Egyptians to hate this Persian rule during which the status of Egypt was unstable and attempts of independence were made and once succeeded by a native man who ruled the country and caused the interval in the Persian rule.

\section{During the Ptolemaic period}

When Alexander the Great started his conquest in $332 \mathrm{BC}$, the Egyptians welcomed him. Because Alexander was wise enough to know that respecting the native religion was everything to the Egyptians, he visited the temple of Apis bull once he entered Memphis and presented sacrifices to him. This led the priests announced him at once as a Pharaoh. Moreover, Alexander made another approaching step, as he visited the temple of Amun-Re at Siwa and announcing himself as being the son of Zeus-Amun. ${ }^{17}$

When Ptolemy Soter gained the rule of Egypt, after the death of Alexander the Great, he was certain that he had to show respect to the ancient Egyptian religion if he wants to maintain stability in his kingdom. Therefore, he shows his respect to the Egyptian religion and so did all the Ptolemaic family. This was probably the reason that made the Egyptians accept this foreign rule that lasted for nearly three centuries. The researcher will present here some proofs on the trials made by the Ptolemies to respect the Ancient Egyptian religion. Once Ptolemy I ruled Egypt, he wanted to integrate Egyptian religion with the Hellenic one. Ptolemy's policy was to find a deity that should win the reverence alike of both groups: The Egyptians and the Greeks. Therefore, he invented god Serapis, who is a modification of the animal god Osir-Apis in a human form (Fig. 1). ${ }^{18}$ But it seems that this god couldn't do the desired task, as the Egyptians refused this new invented god to enter their religious pantheon. The art work can prove this theory, as no trace of the figure of Serapis or even his name is mentioned in the monuments of Upper Egypt that mainly inhabited by the native Egyptians. It was not until the Roman period, that shrines and temples of Serapis were found in Upper Egypt, but also in a small-scale, such as the shrine of Serapis just outside the great Luxor temple that dates to the $2^{\text {nd }}$ century AD, and there is only one temple in Upper Egypt, which is in the city of Akoris and dated back to the Roman era. ${ }^{19}$ However, these temples were intended for the soldiers whose garrisons were 
stationed there. Those soldiers were all foreigners and not Egyptians. ${ }^{20}$ As for the ancient Egyptians, they only knew their famous triad Osiris-Isis-Horus. On the contrary, we can see Serapis mentioned inside Alexandria and El-Fayoum that used to be inhabited by the Greeks.

Another attempt was made when the Ptolemies bond between the Egyptian and the Greek deities. They depended on the commentaries of Herodotus, who previously made this assimilation. In book II of The Histories, Herodotus said that the Egyptians were the one who exported their twelve gods to Greece. ${ }^{21}$ He uses Greek gods' names in reference to Egyptian gods. He is clear in stating that they are the same, but different names. He said that Ptah is Hephaestus, Horus is Apollo, Osiris is Dionysius, Isis is Demeter, and Amun-Re is Zeus. This attempt didn't succeed as the Egyptian used to hold on to their original religion.

Therefore, the Ptolemies realized that there is no way to gain the sympathy of the Egyptians, but worshipping the Egyptian deities. The prominent proof was the animal sanctification that flourished in Egypt in the Late period. As it was known, the Greeks used to mock at those who worshipped the animals. This is emphasized by a comic Poetry written by Anaxandrides ${ }^{22}$ in his play "The cities", dated back to the fourth century BC, he said:

\section{DEMOS TO EGYPT:}

I couldn't have myself allied with you.

Our ways and customs differing as they do.

I sacrifice to Gods, to bulls you kneel,

Your greatest god's our greatest treat, the eel;

You don't eat pork, it's quite my favorite meat;

You worshiped your dog, mine I always beat.

When he's caught stealing; priests stay whole with us,

With you they are gelded eunuchs; if poor puss

Appears in pain you weep, I kill and skin her.

To me the mouse is nought, you see power in her. ${ }^{23}$

Despite that, Ptolemy I dedicated fifty talents of money for the funerals of the dead Apis bull. Ptolemy II asked Apollonios, the finance minister, to provide hundred talents of myrrh destined to the treatment of the cow Isis Hesat of Aphroditopolis. ${ }^{24}$ There is a stela from Mendes, in the Delta, which indicates the visit of Ptolemy II. Different decrees, like the one of Canopus, under Ptolemy III, or that of Memphis, under Ptolemy V, mentioned the interest of the sovereigns or their kindness towards the sacred animals and particularly the Apis of Memphis and the Mnevis of Heliopolis. ${ }^{25}$ Furthermore, Ptolemy VI Philometor assisted in year 24 in the ceremony of the installation of the Bouchis bull at Thebes. The animal, born in year 19 of his reign, had been already consecrated. ${ }^{26}$ Another visit to Bouchis made by Cleopatra VII, accompanied by her brother Ptolemy Philopator. The queen accompanied the animal in the bark of Amun till Arment. ${ }^{27}$ 
There are many representations (stelae) confirm that the Ptolemaic kings participated in the ceremonies of the sanctification of animals. There is the Mendes Stela that is preserved in the Egyptian museum in Cairo Inv.22181 (Fig.2). On it there is a representation of the Mendes Ram accompanied by the royal family that present the offerings to him. Ptolemy II appears surmounted with the double crown, and holds a jar of perfume. The inscription reads: "the presentation of the perfume to his father and the presentation of the myrrh to the nose of the god". Behind the king stands the queen Arsinoe holding the ankh sign in one hand and wheat in the other. She says: "I protect you in your crown, therefore, you are greater than all of the other divinities". Behind her, stands the young Ptolemy followed by the Nekhbet snake that wears the crown of Upper Egypt. the stela reported that Ptolemy II exempted the temple of the ram from great part of taxes that were paid for the royal house. We can read: "His Majesty ordered that no bread-tribute should be paid as regards the Ram-temple and its district, nor in its name". ${ }^{28}$

There is also the stela that belonged to Ptolemy $\mathrm{V}$, who is represented wearing the Pharaonic costume and presents the offerings to the Buchis bull. It is preserved in the Egyptian museum in Cairo, Inv. JE 54313, and was found in the Bucheum of Armant "Hermonthis (Fig. 3). We can see The Buchis bull wears his characteristic headdress of sun disc, two plumes and double uraei. The hieroglyphic name reads: living spirit of $\mathrm{Re}$ and (herald of $\mathrm{Re}$ ). Over his shoulder flies a falcon. Before the bull stands the king offering the emblem of field symbolizing the production of Egypt. He wears the blue war crown, a corselet and kilt with triangular apron. The cartouche of Ptolemy's queen, Cleopatra I, is also present, although she is not depicted. The text is dated back to 14 February $180 \mathrm{BC}$. It gives further information declaring that the bull was thirteen years, ten months and twenty-four days old (or twenty -eight days) at death, having been born in year 11 of Ptolemy's reign, in march $184 \mathrm{BC}$ in the town of Taareq, but was only installed as Buchis the year before its death. ${ }^{29}$ At Edfu, Ptolemy IX Soter II was represented in different drawings related to the installation of a living falcon on the throne of Horus. At Philae, on the walls of the pylon, Ptolemy XII Neos Dionysos witnessed the enthronement of the sacred falcon. ${ }^{30}$

Later, the Greeks who lived in Egypt incorporated into this religion. This can be confirmed through the dedications that were made to the sacred animals that used to carry Greek names. For example, in the region of El-Fayoum that was mostly inhabited by Greeks, the main god was the crocodile Sobek whose name was changed by the Greeks to be Pnepheros, Souchos or Sokopichonsis. There was also a city in El-Fayoum called Crocodilopolis. ${ }^{31}$ Dunand mentioned that there are many inscriptions from El-Fayoum dating back to the second and the first century BC mentioned the consecration of various monuments to the crocodile god made by the Greeks. ${ }^{32}$ There are also statuettes and stelae that were left by the pilgrims as an ex - voto. For example, there is a crocodile statuette inscribed with the name of Apollonios son of Apollonios. ${ }^{33}$ There is also a stela dated back to $97 \mathrm{BC}$ made by a man called Apollonios son of Ischyrion. ${ }^{34}$

Moreover, The Greeks created a new sacred animal in Egypt; which is the Agathos Daimon; the protector god of Alexandria (Fig. 4). This legend told us that this snake-god is related to the construction of the city, as during the works a snake appeared to the workers and terrified them who eventually killed it. Also, small snakes appeared and entered the houses that have been just built. Later, Alexander the Great ordered to build a sanctuary for this snake. The importance of this god continued during the Roman era; as it appeared on many stelae. In addition of being the protector god of Alexandria, the Agathos Daimon played other roles. It was considered the protector of the 
deceased; therefore, it appeared in a painting, decorating the second chamber in Tigran tomb dated back to the $2^{\text {nd }}$ century AD. ${ }^{35}$

The Ptolemies also venerated themselves as used to be done by the Pharaohs. Ptolemy I attested the dynastic cult as he elevated Alexander to the level of the state cult. The priest of this cult was considered the high priest in the whole land of Egypt. The cult of Alexander the great continued during the Roman era until the reign of Hadrian. The Ptolemaic dynastic-cult didn't become officially established until Ptolemy II set the cult of his father Ptolemy I and his mother Berenice I who were worshipped under the title "Theoi Soteres" meaning "the savior gods". He also created a festival in his father's honour called "Ptolemaieia". ${ }^{36}$ Each successive Ptolemaic ruler till the reign of Cleopatra VII was deified. $^{37}$

The Ptolemies continued to express themselves as the offspring of the gods. Therefore, a mammisi or a birth house used to be attached to the temple in which a celebration for the birth of the third member of the divine triad alongside with the birth of the kings was celebrated. When Cleopatra VII gave birth to Caesarean, she doubted that he would not be accepted by the Egyptians because he was the son of Julius Caesar, a Roman man. Therefore, she invented a divine birth story for her child resembling the one used before by Hatshepsut and Amenhotep III. This story was inscribed on the walls of the temple of Arment, in which she mentioned that Isis - in the form of Cleopatra - was visited by Amun-Re and that a child was conceived and brought forth by the queen. ${ }^{38}$ There is a scene from this temple representing the birth of "Horus the sun, the child" in the presence of Amen-Re, Nekhbet and Cleopatra VII. The inscriptions referred to the mother of the child as being Rat-Tawy and the father is Amen-Re. Nearby, seated on a couch, two identical cow-headed goddesses each suckle a baby. The two infants were identified as being Harpre and Caesarion (Fig.5). ${ }^{39}$

The Ptolemies were keen on being represented on the walls of the temples honouring the Egyptian gods and presenting offerings to them. The necessity of this is explained in Papyrus Jumilhac, that dated back to the end of the Ptolemaic period. This papyrus mentioned a description of a cult in the $18^{\text {th }}$ Nome of Upper Egypt and includes a discourse on the importance of maintaining the cult of the deities. If the king and the priests were to fail to do so, Egypt would be obliterated. ${ }^{40}$

The Ptolemies also built a good bond with the priests who used to affect the thoughts of the Egyptians. The priests used to gain great power in the society, throughout the Pharaonic period they placed their hands on the fortune of the temples especially the lands. The land that was dedicated to the Egyptian temples represents one third of the whole Egyptian cultivated land. Therefore, the Ptolemies offered the priests more lands. They also received special concessions (such as: partial or total exemption from certain taxes) and dispensations. ${ }^{41}$ The Ptolemies began to take care of the temples by restoring them or building new temples. Because of this good relationship with the priests; they used to support the Ptolemaic king, especially throughout the third century BC. This can be noticed in the Canopus decree in $238 \mathrm{BC}$, in which the priests praised the Ptolemaic king, and established a cult for his dead daughter Berenice. ${ }^{42}$

Thus, we can say that the first three Ptolemaic kings were capable of sustaining the stability of their kingdom. Despite the revolt that occurred under the reign of Ptolemy III, it didn't achieve any success because it was not supported by the priests who were pleased with the king's gifts. The tension between the priests and the Ptolemies occurred in the second century BC, when the Ptolemies started to weaken the priests' power by taking away some of their rights. For example, they added some 
amendments to the administrative system of the temple. They added the position of the "Epistates", who was a royal employee inside the temple, whose job was to direct the goods of the temple domain and have under his supervision the tax collectors. Thus, the temple fortune was in the hand of the king. ${ }^{43}$ The Ptolemies started to have the right to sell the priesthood position, and if the priest wants to

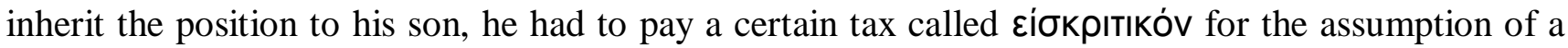
priestly rank. The Ptolemies started to reduce the number of the temples that granted the concession of the asylum. They also imposed taxation on the priests, who were previously exempted from any taxation. For example, the priests paid a tax called غ́тıбтатıкóv to fund the overseers of the temples "Epistates". 44

Therefore, when the Egyptians began to complain about the economic status of the country and began to gain more confidence, especially after their role in the Battle of Raphia that was the reason of winning the fourth Syrian War, the priests supported this revolt. ${ }^{45}$ The priests' support made the revolt very effective; as it started in $216 \mathrm{BC}$ in the Delta and reached to Thebes in $206 \mathrm{BC}$. One of the effects of this revolt is that the construction of the temple of Edfu was stopped in $206 \mathrm{BC}$. The priests of Amon-Re and the priests of Isis organized the rebels and support the head of this revolt "Hr-wnnfr" and "Anch-wn-nfr" who ruled the Thebaid at that time as kings for 20 years and carried some religious titles such as "The beloved of Isis and the beloved of Amon-Re". 46 there is a demotic papyrus dates back to $216 \mathrm{BC}$ from Elephantine refers to an official letter in which one of the priests was invited to attend the victory celebration of the Battle of Raphia in Alexandria in order to present the ivy wreath to Ptolemy IV and the priest refused this invitation. ${ }^{47}$ Because of the great power of the priests of the Thebaid, Ptolemy IV succeeded in putting the revolt of the Delta to an end, but he lost control over the Thebaid. ${ }^{48}$

When Ptolemy V ascended the throne, he faced the danger of the revolts. He, or precisely the court man Sosibius, was aware that in order to be capable of crushing these revolts he has to appease the priests and getting them on his side. A celebration took place in Memphis in $197 \mathrm{BC}$, in which the little king was consecrated by Egyptian priests at the old capital, Memphis, with the coronation ceremony proper for a native Pharaoh. It is considered the first attested case of a Ptolemaic ruler being crowned Pharaoh of Memphis. He also heaped on the temples many grants and donations. He has adorned the temple of Apis, spending on it no small sum of gold and silver and precious stones. He founded temples and shrines and altars and restored those in need of repair. ${ }^{49}$ All of this made the priests wrote a decree of honour to the deeds of Ptolemy V on what's known as the Rosetta stone.$^{50}$

It seems that Ptolemy $\mathrm{V}$ succeeded in getting the priests on his side. When he besieged the city of Lycopolis in $197 \mathrm{BC}$ and caught the heads of the rebels, tied them behind his chariot, dragged naked, misused, and put to death; the priests didn't find anything odd in this scene and accused the rebels of harming the country and sacrilege the temples. ${ }^{51}$ This is also mentioned on the Rosetta Stone:

"he took by storm the city in a very short time and destroyed all the impious men who were therein, reduced to subjection those who had rebelled. And the men who had led astray the rebels in the time of his father and had stirred up the revolt in the country, and had committed sacrilege in the temples" ${ }^{\prime \prime 2}$

King Ptolemy $\mathrm{V}$ was still facing a challenge in regaining the Thebaid from the rebels. He assembled the priests in a meeting in Alexandria in which the priests admitted that Ankhmachis (the Egyptian 
ruler of the Thebaid) is an enemy of the gods because he opposed the legitimate Ptolemaic king. ${ }^{53}$ It wasn't until 187-186 BC that Ptolemy V got rid of the revolt in the Thebaid region. Some priests who were supporting the rebels escaped to Nubia. The king here sent a letter written in Demotic $187 \mathrm{BC}$ to three escaped priests informing them that they were forgiven and asking them to return to Elephantine. $^{54}$

It seems that starting from the reign of Ptolemy V; the Ptolemaic kings changed their ideology towards the priests and the Egyptian religion. Thus, a great number of priests became on the same side of the king. This led some Egyptians to attack the priests. There is a document dated back to 164 $\mathrm{BC}$, reveals an attack made by the rebels on an Egyptian temple in El-Fayoum, because the priests of this temple were taking the side of the Ptolemaic king.

"To ..........., a chief of the body-guard and strategos, from ............, overseer of the temple of Ammon at Moeris of the 45-arouras holders. The shrine in the said temple having been (destroyed) by the men of Antiochos in ... of the 2nd year, and the ground having later been regained (?), the temple was restored to its ancient state. Afterwards when the Egyptian rebels had attacked it and not only thrown down parts of the temple but split the stone-work of the shrine and carried off the door-fixtures and other doors to the number of more than 110 and also torn down some of the boarding, after some time ... I came forward and stopped up all the gates and breaches in order that the remaining colonnades might be held together. But now..... 55

Ptolemy VIII continued the ideology of appeasing the priests; he issued a decree in $144 \mathrm{BC}$ in which he exempted the priests from certain taxes, restoring the temples and building new ones, rights of asylum was subsisted at the temples. ${ }^{56}$ The same king issued another decree in $118 \mathrm{BC}$, in which he has decided that the temple land and other sacred revenues, which belong to the temples shall remain assured to them, and that the temples shall receive the tithes which they used to receive from holding and gardens and other land. No one shall be allowed to take anything from these sources of income. No one shall take away by force anything of what has been dedicated to the gods, nor apply forcible persuasion to the superintendents of the sacred revenue, whether derived from villages or land or other temple revenues, nor shall the tax on associations or the crown-tax or the artaba-tax be paid upon what has been dedicated to the gods, nor shall the temple lands be worked on any pretext, but they shall be left to be administered by the priests. He decreed that the expenses for the burial of Apis and Mnevis should be demanded from the crown revenues, as in the case of the deified personages. Likewise, in the case of the other sacred animals the sums required (shall be paid by the crown). He decreed that no one is to be dragged away of forcibly ejected from the existing places of asylum. ${ }^{57}$ Therefore, Ptolemy VIII was entitled Eurgetes II "The benefactor", although he was hated by the Egyptians because of his cruelty as he set a great struggle with his brother Ptolemy VI, killed his nephew Ptolemy VII, married a mother and a daughter in the same time, avenged from the Alexandrians by expelling the intellectuals and the artists, the matter that led the Alexandrians set the fire in the royal palace, he also killed his own son Ptolemy Memphitis, a civil war was set against his first wife Cleopatra II. ${ }^{58}$

Because of these grants and donations that were offered to the priests, they continued in helping the Ptolemaic kings in facing the revolts. There is a letter sent from Platon (the Strategos of Thebes) to the priests of Pathyrites (Gebelein) asking them to resist and blockage the revolt, promising them that Ptolemy IX Soter II reached Memphis and asked Heracleus to subdue the city of Thebes. ${ }^{59}$ It seems from this document that the priests at that time were delegated to protect the city from the rebels. On 
the other side, there were some priests who still stand against the king, despite of the donations, such as the priests of Amun at Thebes, who used to support the rebels. ${ }^{60}$

We can conclude here that the Ptolemies used the religion to stabilize their rule in Egypt, because they were aware of the effect of the religion on the Egyptians. They followed many ways to reach their goal. Firstly, they tried to incorporate the Greek religion into the Egyptian one, by inventing a new god "Serapis", and assimilating their Greek gods with the Egyptian ones. When this way didn't succeed, because the Egyptians refused entering any foreign god to their pantheon; the Ptolemies were obliged to show respect to the Egyptian religion. They were represented presenting the offerings to the animal-gods, whose cult was very odd to the Greeks. They also venerated themselves as it used to occur during the rule of the Pharaohs. They also began to appease the priests and building new temples and restoring the old ones. Those priests were the reason that makes the late Ptolemies being capable of crushing the revolts occurred in their reigns.

\section{During the Roman period:}

The Roman Emperors were not ruling from Egypt, despite of that, they continued to use the religion to affect the Egyptians and stabilize their rule in Egypt. Therefore, the practices and beliefs of the sacred animals in Egypt continued, however, less than the Ptolemaic period and vanishes with the appearance of the Christian religion. To the eyes of the Romans, the representation of the gods in an animal form was inappropriate, in truth a scandal. This is testified by a scene by Virgil, talking about the last battle against Cleopatra, about the confrontation between the venerable divinities of Rome and the barber Orient, which is also a victory of a religious universe with gods in human forms upon another foreign universe which represent the gods in inappropriate forms.

In the midst, the Queen, sounding her native timbrel, wildly calls her minions to the fight, nor yet can see two fatal asps behind. Her monster-gods, barking Anubis, and his mongrel crew, on Neptune, Venus, and Minerva fling their impious arms ${ }^{61}$

Octavius "Augustus" when entered Egypt, he refused to visit the bull of Memphis and the incarnation of Apis. However, later Emperors showed respect to the animal gods. Emperor Hadrian witnessed the installation of the Apis bull in Memphis during his visit to Egypt. On the stelae of Buchis-bull, we can see the adoration of emperors as late as Valerian and Diocletian. There is a limestone stela found at Armant "Hermonthis », dated back to the Roman period, and preserved in the British Museum EA 1695 (Fig. 6). The stela was dedicated to the Buchis bull which was born in 27 march 254 AD, in the first year of Valerian "253-260 AD "and died on the $27^{\text {th }}$ of December $273 \mathrm{AD}$, in the fifth year of Aurlian "270-275 A.D ". The Names of the two emperors were written in a cartouche, on the other hand, there is no name for the king who presents offerings to the bull. The upper part is decorated with a sun-disc. There are also two jackals with the keys of the Netherworld hanged around their necks. The main scene represents the emperor depicted in a Pharaonic form presents the offerings to the Buchis Bull that is represented lying on the ground, crowned with the sun-disc and the two feathers. ${ }^{62}$ 
A Bas-Relief on the last register of the west wall of the roman Hypostyle Hall, Temple of Esna, represents emperor Decius presents offerings to the ram "symbol of the god Khnum (Fig. 7). ${ }^{63}$ A Raised relief on the inner column of the roman Hypostyle hall, Temple of Esna, represents Domitian kneeling and offers the ankh" symbol of life", the W3S "symbol of prosperity" and the Jed "symbol of stability " to god Sobek who is represented in the shape of a crocodile surmounted with a sun disc and a snake (fig. 8). ${ }^{64}$

The sacred animals were also represented on the coins accompanied by the emperors. Through studying the Katalog Alexandrinischer Kaisermünzen der Sammlung des Instituts für Altertumskunde der Universität zu Köln , It can be noticed that there is just one coin was made for the sacred animals during the reign of Tiberius, during the reign of Claudius two coins were made, ten coins during the reign of Nero, 6 coins during the reign of Vespasian, 13 coins during reign of Domitian, during the reign of Nerva just one coin was made, 24 coins during the reign of Trajan, and 31 coins during the reign of Hadrian. Most of the coins were made from Bronze. ${ }^{65}$ It's worth mentioning also that representing the Egyptian sacred animals on the coins didn't occur in the Ptolemaic period; on the contrary, we can see some Greek birds such as the eagle and the owl. thus, it seems that this is a new way by which the emperors emphasized their respect to the Egyptian religion. It seems that the emperor didn't really worship the animal gods; however, he had to be represented in this way inside Egypt, in order to maintain his control over the country. For example, Emperor Decius ruled only for 2 years, during which he didn't visit Egypt; however, he is depicted presenting the offerings to the ram on the walls of the temple of Esna.

The researcher here opposes the idea claiming that such representations were made by the Egyptian priests as a propaganda for their religion, and thought that this is a way of appeasing the Egyptians made on order from the emperor or at least from the prefects after being permitted by the emperor. This can be very clear in the representations appeared on the coins that were minuend under the supervision of the government with no interference of the priests.

It is notable also that the emperors were very keen on establishing and renewing the temples, even if they are not convinced with the religion. Emperor Augusts refused to have Egyptian shrines within the central area of Rome known as the "pomerium". While he was in Sicily in 21 BC, troubles that broke out in Rome because of the selection of the consuls, in which the Isiaci took a part, forced him to send M. Agrippa to the city to issue a decree prohibiting the practice of the cult within one mile of the pomerium. ${ }^{66}$ On the other hand, we can see the representations of Augustus on the walls of the temples in Egypt, presenting the offering to Isis, such as the one found on the walls of the temple of Dendur in Nubia. He was also figured in the temple of Isis at Philae as the Pharaoh loved by Isis (Fig. 9). ${ }^{67}$ During the reign of Emperor Tiberius, in year $32 \mathrm{AD}$, a Roman knight called Decius Mundus masqueraded as the god Anubis and raped a respectable and gullible noble Roman matron called Paulina in the Isis temple on the Capitoline Hill, after she refused to sleep with him for two hundred thousand drachms. Therefore, the temple was closed, the Emperor threw the statues of Isis into the Tiber and the Isis's priests were crucified. ${ }^{68}$ Tacitus mentioned in his Annales about the persecution happened to the believers of the Egyptian cult: ${ }^{69}$

"It became over it debates, that one should drive out the Egyptian and Jewish cults. The senate grasped a decision, that 4000 men that were infected by this superstition, generally according to its age, should be sent to Sardinia Island. If they died because of the unfavorable 
climate, so the damage would be low. The remainders should either set aside their unholy rites up to a fixed date or should leave Italy". ${ }^{70}$

On the other hand, Tiberius was represented on the walls of the temple of Isis at Philae presenting offerings to Isis and Osiris. ${ }^{71}$ Other emperors were represented on the offering scenes on the walls of the Egyptian temples. It seems that this was not an interest from the emperor to be represented in that way, but it became a cultic tradition and a theoretical role to maintain his control over Egypt. The construction and decoration of Egyptian temples decreased in the third century AD because of the economic crisis occurred at that time.

It seems also that the Alexandrians used their gods as a support in their disputation with the Jews. This reached us through the Acta Alexandrinorum that told us about a disputation occurred between the Alexandrians, and the Jews during the reign of Emperor Trajan. The Alexandrians here sent a deputation to Rome with some complaint against the Jews, as the latter had immediately also sent a deputation of their own. We knew also that the Alexandrians took with them the bust of Serapis. It seems that the emperor was on the side of the Jews, especially that the Empress Plotina approached the senators in order that they oppose the Alexandrians and support the Jews. The papyrus told us that while Hermaiscus was speaking to the Emperor who was talking improperly, the bust of Serapis that they carried suddenly broke into a sweat and Trajan was astounded when he saw it. Crowds soon gathered in Rome and numerous shouts rang forth, and everyone began to flee to the highest parts of the hills. ${ }^{72}$ This accident probably emphasizes the power of Serapis against that of Yahweh or to show the disastrous effect that he could have on the Roman people if the Alexandrian envoys were scorned. In any case, this is a proof of using the religion in gaining a political goal.

This type of miraculous act was later used by the emperors themselves. By the time of Vespasian, a story reached us about the miraculous power of the Emperor that was given to him by the aid of Serapis. we were informed that when the emperor was in Alexandria before his accession, two men, one blind, the other with a maimed hand, came to him seeking a cure on the directive of Sarapis. After some delay for consultation with physicians as to whether these infirmities could be overcome, Vespasian affected the desired cures. ${ }^{73}$ This was mentioned in the Historiae of Tacitus: ${ }^{74}$ This miraculous power had a political goal. It was well known that the year preceded the reign of Vespasian was known as "the year of the four Emperors", in which four Emperors (Galba, Otho, Vitellius, and Vespasian) accessioned the throne in the same year (year 69 AD) after the death of Nero. Vespasian was already in Alexandria in November 69 for securing the grain supply or that he didn't want to participate in the bloodbath that occurred in Rome struggling on the throne. ${ }^{75}$ At that time the troops in Egypt, proclaimed Vespasian emperor and prepared for him a lavish reception in Alexandria, in which he was received as the New Serpais ${ }^{76}$ and performed his miraculous power in order to affirm that he was the one that was chosen by the god.

The same thing can be affirmed by another story mentioned by Suetonius saying that earlier Vespasian spent time alone in the sanctuary of Serpais and saw in a vision a man named Basilides conferred upon Vespasian certain objects (loaves and crowns). ${ }^{77}$ This dream was a prediction that the emperor was chosen by the god. It is obvious here that Vespasian by these acts wanted to gain the support of the eastern provinces against the other claimers.

Emperor Marcus Aurelius paid respect to the Egyptian gods and the Egyptian priests, especially that one of them, Arnuphis, was responsible of the miracle of the rain during the war against the German 
people in what is called the Macromanni war in year 172-173 AD. The Roman army in this war suffered from fatigue, wounds, the heat of the sun, and thirst. Suddenly a rainstorm occurred and the thunderbolt that accompanied the rain struck and destroyed one of the enemy's engines. This event was used as a propaganda for Marcus Aurelius that he was under the protection of the gods, especially that his power was not secured. Each historian when dealing with this miracle attributed it to a certain god. The miracle was recorded on the column of Marcus Aurelius at Rome, but the scenes here attributed the Miracle to an unidentifiable deity (fig. 10). For the Romans, it was Jupiter, who was responsible for the miracle. ${ }^{78}$ It was Dio cassius that attributed it to an Egyptian priest called Arnuphis who invoked the god Hermes-Thoth for rain. ${ }^{79}$ Because of this miracle Marcus Aurleius promised to construct a temple with an Egyptian style, whose image was found on the reverse of one of the coins that related to his era (Fig. 11) ${ }^{80}$ The question here is why Dio Cassius involved the Egyptian deity into this event. It could be related to the interior situation in Egypt, where a revolt in 172 occurred known as the revolt of the boukoloi, led by the Egyptian priest Isidoros. The boukoloi was political groups of lower-class desperadoes who fought against the Roman forces and Roman religion in defense of Egyptian political and religious independence. The rebellion eventually spread to cover a great part of Egypt and lasted for several years. During which, Isidoros defeated the Romans in battle and had almost conquered Alexandria when Avidius Cassius, the governor of Syria, managed to defeat them after several battles. ${ }^{81}$ This revolt mentioned in the biography of Marcus Aurelius. ${ }^{82}$ It is obvious here that Marcus Aurelius intended to involve Hermes-Thoth in the rain Miracle, in order to demonstrate to the local population and legions that a local deity protected his army on the battlefield.

Emperor Caracalla visited Alexandria in $215 \mathrm{AD}$, and dedicated to Sarapis the sword with which he supposedly had killed his brother Geta. The Alexandrians were mocking at Caracalla. They had laughed at his dressing like Achilles and Alexander the Great, while in person he was short. The Alexandrians hated Caracalla for killing his younger brother Geta. These jokes reached the ears of Caracalla and they were not forgotten. During his visit to Alexandria, he issued a decree that all the youths of Alexandria of an age to enter the army should meet him in a plain on the outside of the city. The Emperor ordered to slaughter the Alexandrians. During his slaughtering of the Alexandrians he made the temple of Serapis, his headquarters, issuing orders from there. ${ }^{83}$ It seems that Caracalla wanted here to give his decisions a religious approval.

After the entrance of Christianity, attempts were made to stop the spread of this pagan religion. These attempts were failed and had seemingly only strengthened Christianity. Therefore, Emperor Julian the Apostate thought of another way to fight Christianity, he ordered the opening and the construction of pagan temples. He venerated the sun, which Sarapis-Helios was one of her formative. In his letter to the Alexandrians he proclaimed that the Great Sarapis contributed in giving him the power. ${ }^{84}$

The Roman Emperors deified themselves, as it was the habit in the Pharaonic and Ptolemaic period. Emperor Augustus established an Imperial cult in Alexandria. The cult center in was in Alexandria and was headed by a high priest appointed by the Emperor as his representative in Egypt. This priest was always of Roman origin and had the title of "High priest of Alexandria and all Egypt". In Whole Egypt, there are archaeological and papyrological references to Imperial temples called Sebasteia, or Caesarea. ${ }^{85}$ The biggest temple was in Alexandria that was constructed by Cleopatra VII and then rededicated to Augustus. The Jewish writer Philo of Alexandria described the Caesareum of Alexandria as follows: ${ }^{86}$ 
"Nowhere is there a holy place comparable to the Sebasteion. Great and famous, filled with offerings like nowhere else, surrounded with paintings and statues of silver and gold, a vat sacred precinct with covered ambulatories, libraries, rooms, sacred groves, gates, large open spaces, open courts, all decorated in the most extravagant manner".

It seems that there were also other Imperial temples in the provinces. There is a temple of Augustus on the island of Philae. ${ }^{87}$ Another temple of Augustus was located in Karnak, next to the causeway of the temple of Amun, in front of the first pylon. ${ }^{88}$ The papyri records the existence of such temples in other provinces such as Canopus, Antinopolis, Elephantine, Hermopolis, Herakleopolis, Hermopolis, Oxyrhynchus, Arsinoe, and Philadelphia.

It seems that the imperial cult didn't have the same effect on the Egyptians, like the Ptolemaic cult. According to the Egyptians, the Emperor, unlike the Ptolemies, was not a god. Therefore, no private imperial cult was practiced by the populace outside the official imperial centers and there were no native priests for this cult, the priest of this cult were Romans. However, in certain events the imperial cult was used in achieving political goals. This can be noticed during the reign of Caligula, who was known for his fondness of Egypt and the Egyptian religion. This was probably due to his father Germanicus, who showed an interest in this cult, and the atmosphere in which he was raised at his Grandmother Antonia's house along with the Egyptian princes. We know from Philo that he wished to be called Soter, Eurgetes, and Epiphanus the epithets of the Ptolemies. Philo and Suetonius mentioned that Caligula wished to make Alexandria his capital city, but he died before executing this project. He was also the one that introduced the idea that the Roman ruler was already divine in his lifetime. He also chose to be married to his sister Drusilla like the Ptolemies. In his palace, the majority of the servants had an Egyptian origin. ${ }^{89} \mathrm{He}$ was nearly the only Emperor that made a statue of his own depicting as a Pharaoh. In order to create a close bond with the Alexandrians, he issued a decree ordering the Jews to venerate his statue. When the Jews refused to obey this decree, the persecution broke out in $38 \mathrm{AD}$. The Alexandrians demanded that statues of the emperor to be erected in the synagogues. Flaccus, the Roman governor, from his knowledge of the emperor's peculiarities, did not dare to oppose them; he acceded to all the demands. In quick succession, Flaccus ordered the placing of statues in the synagogues; and finally permitted a general persecution to them. Some of the synagogues were destroyed, and some desecrated with an image of Caligula. ${ }^{90}$

The same act was lately made by Decius in his fight against Christianity. Decius issued an edict in 250 required that all Roman citizens take an oath to the emperor, then make a sacrifice and pour a libation to the Roman gods and the Emperor statues. The sacrifice should be done in the presence of a Roman magistrate and a signed certificate will be given to those who fulfilled their worship. Number of Christians were put to death for refusing to perform the sacrifices, many others apostatized and performed the ceremonies, and others went into hiding. ${ }^{91}$

It seems that the Roman Emperors when they interfered the religion in their acts, they were unbeatable. the Roman Emperors started to have a new policy towards the Egyptian priests; as they reduced the revenues of the temples in order to decrease the financial support of the priests, they deprived the temples of the right of the asylum. Despite of this new policy, no revolt occurred in Roman Egypt headed by a priest except for the one happened in the reign of Marcus Aurelius that was mentioned before. All the troubles and revolts occurred in Egypt during the Roman era, were only because of the struggle between the Alexandrians and the Jews. It seems that this religious-cover proved a success during the Roman era. 


\section{Conclusion}

The ancient Egyptians were very attached to their religion, the matter that made all the rulers throughout the ages using the religion in achieving political goals. This started in the Pharaonic period, when the Pharaoh claimed to be the representative of Horus on earth, and in later ages claimed to be the son of the god, and even a god in order to maintain his control on the Egyptians. When the foreigners ruled Egypt, they had to pay respect to the Egyptian religion or else they will be refused by the people such as the case of the Hyksos, and the Persians. Thus, when Alexander the Great conquered Egypt, he was coronated as a Pharaoh in Memphis and went to the temple of Amun at Siwa, where he was announced to be the son of Amun. The Ptolemies kept this policy in ruling the country for almost 300 years. Although there was an attempt made by Ptolemy I at the beginning of his rule to find an intersecting point between the Egyptian and the Greek religion, such as creating a new god "Serapis", and bonding between the Egyptian and the Greek gods, these attempts failed and the Ptolemies had to respect the Egyptian religion. Thus, the Ptolemies worshipped the sacred animals, erecting temples for the Egyptian gods, venerated themselves as used to be done by the Pharaohs, and built a good bond with the priests who used to affect the thoughts of the Egyptians. Those priests were the reason that makes the late Ptolemies being capable of crushing the revolts occurred in their reigns. The Romans also used the religion in stabilizing their rule in Egypt that lasted for another 600 years. The Romans kept the same policy of the ancestors in respecting the sacred animals, erecting temples for the Egyptian gods, and venerating themselves. The Romans invented a new method which is the miracles. Here the Emperor claimed that he got a special aid from the god, this appeared in the reign of Vespasian and Marcus Aurelius. It seems that this new method had an impact on the Egyptians, as no revolts made by the Egyptians during the Roman era, except for the one occurred at the beginning of the reign of Augustus and that occurred during the reign of Marcus Aurelius. Later, the Emperors used the religion in their struggle against the Christians. 


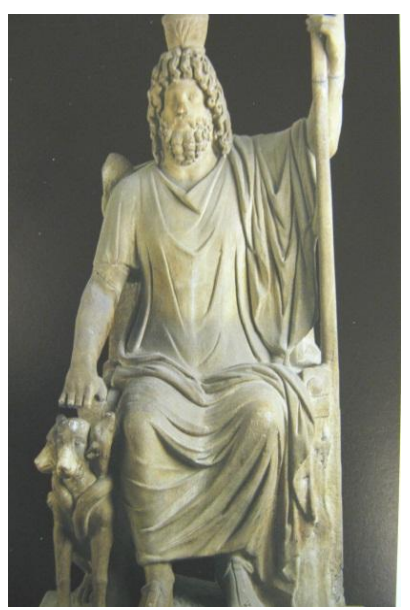

Fig. 1

\section{Serapis with Cerberus}

Ref: Anna Swiderek, Serapis et les hellenomemphites (Brussels, 1975).

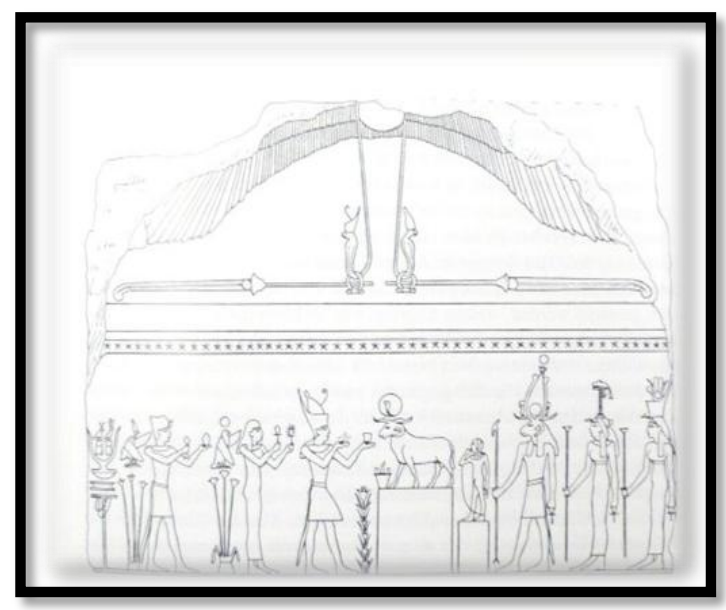

Fig. 2

The Mendes Stela: Ptolemy II offers to Mendes Ram

The Egyptian museum in Cairo Inv.22181

Ref: Hölbl, Geschichte des Ptolemäerreiches, Abb.6 


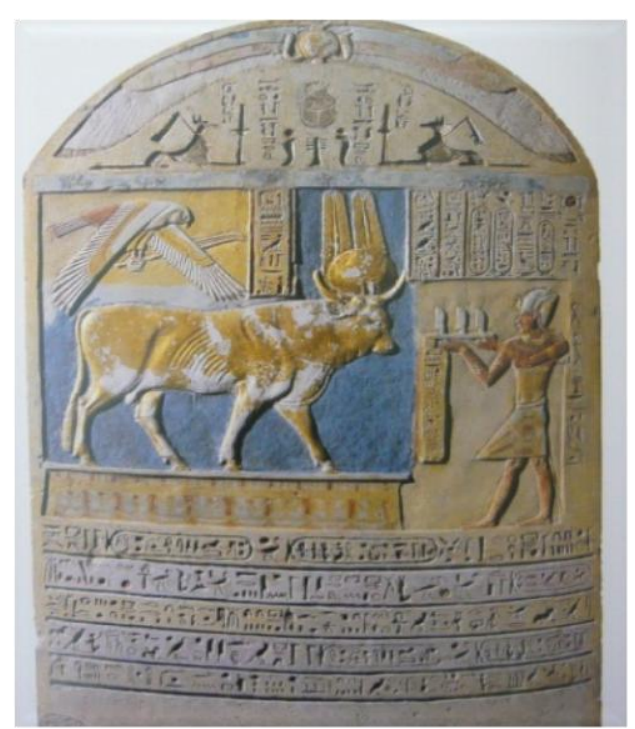

Fig. 3

Stela, Ptolemy V offers to the Buchis Bull

The Egyptian museum in Cairo, Inv. JE 54313

Ref: Robert, Bucheum, Vol. 2, Pl. XL.

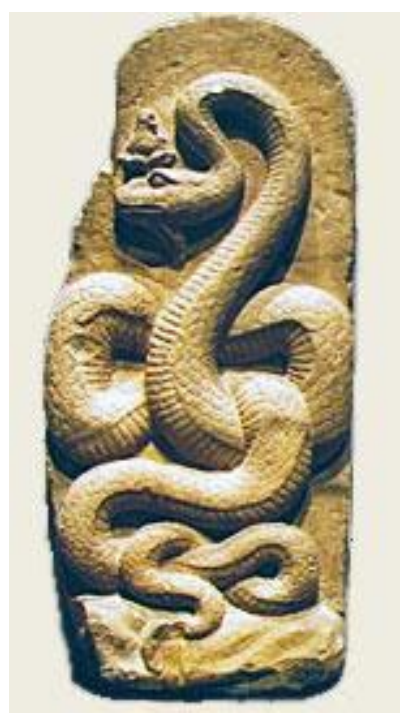

Fig. 4

\section{Agathodaimon}

Ref: Wisser, Gotter und Kulte im Ptolemaischen Alexandrien. 

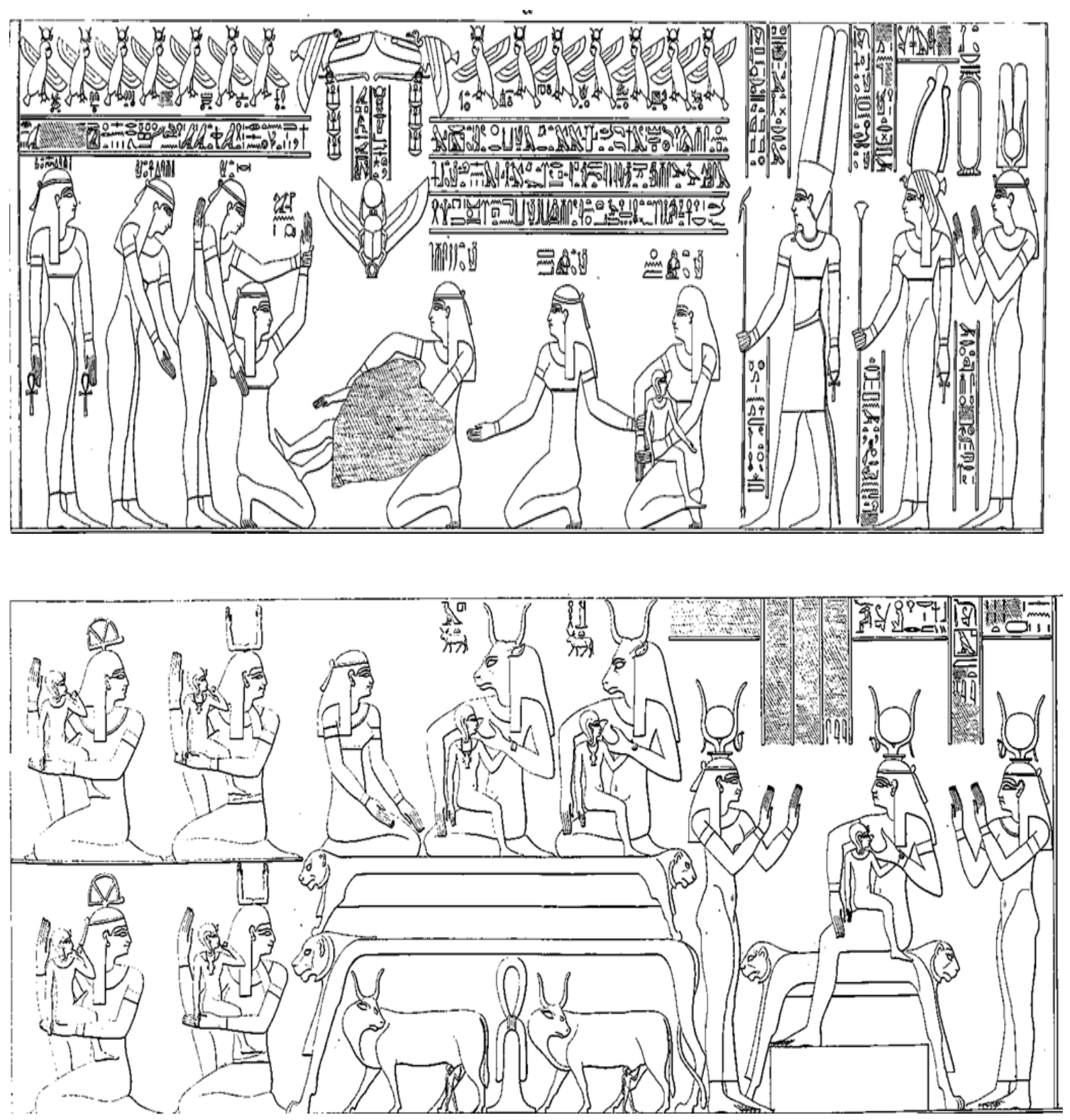

Fig. 5

Birth of Caesarion, temple of Armnet

Ref. Carl Lepsius, Denkmaler aus Aegypten und Aethiopien, IV (Berlin, 1849-1859), 59 b, 60 a 


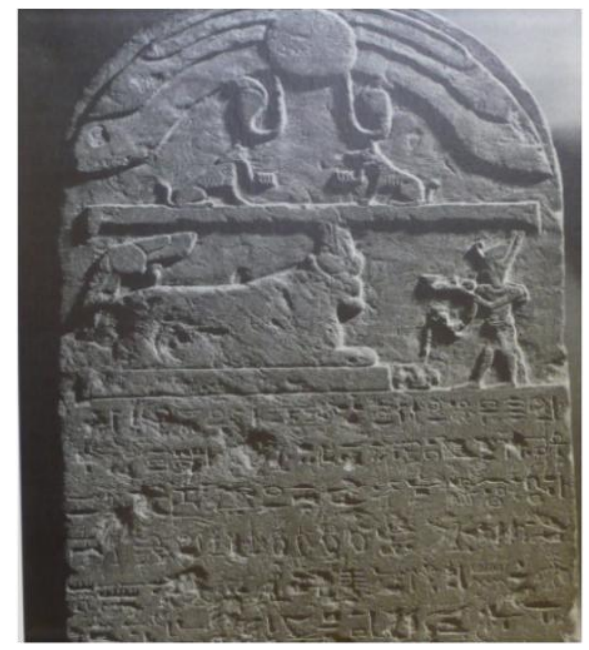

Fig. 6

Limestone stele from Armant, dedicated to the Buchis bull.

London, British Museum Inv. EA 1695

Ref. Hölbl, Altägypten im römischen Reich, Abb. 31

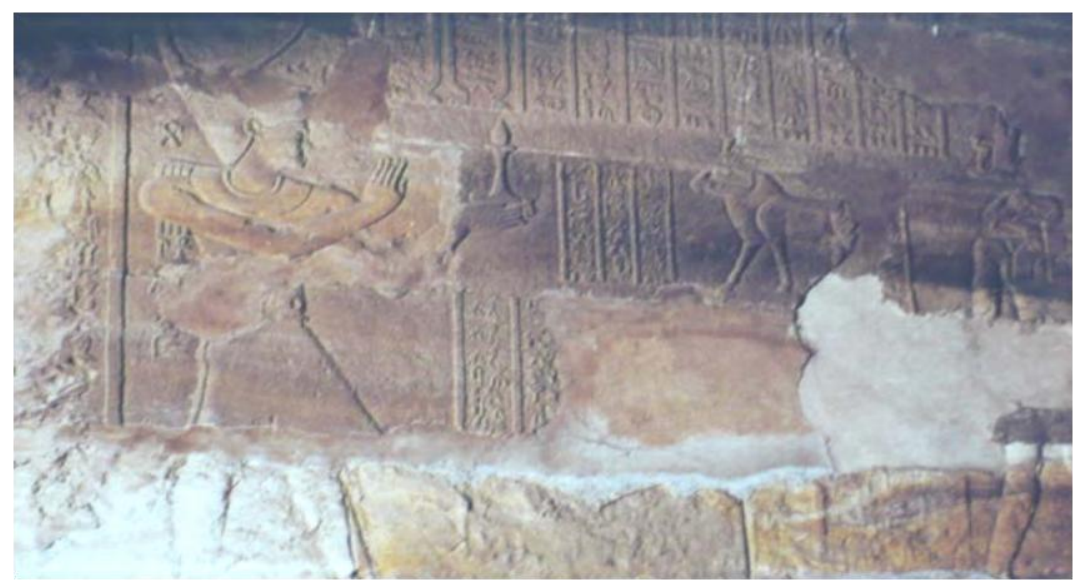

Fig. 7

Emperor Decius offers to the ram god, Esna Temple

Ref. Hölbl, Altägypten im römischen Reich, Abb. 155 


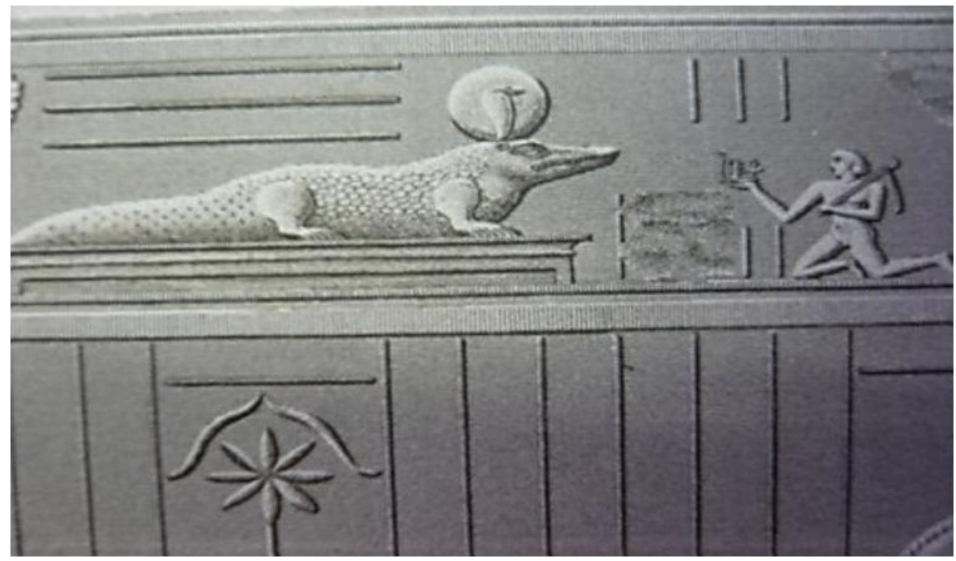

Fig. 8

Relief, column of the Roman Hypostyle Hall in the Temple of Esna. Ref. Description de l'Égypte, Pl. 82

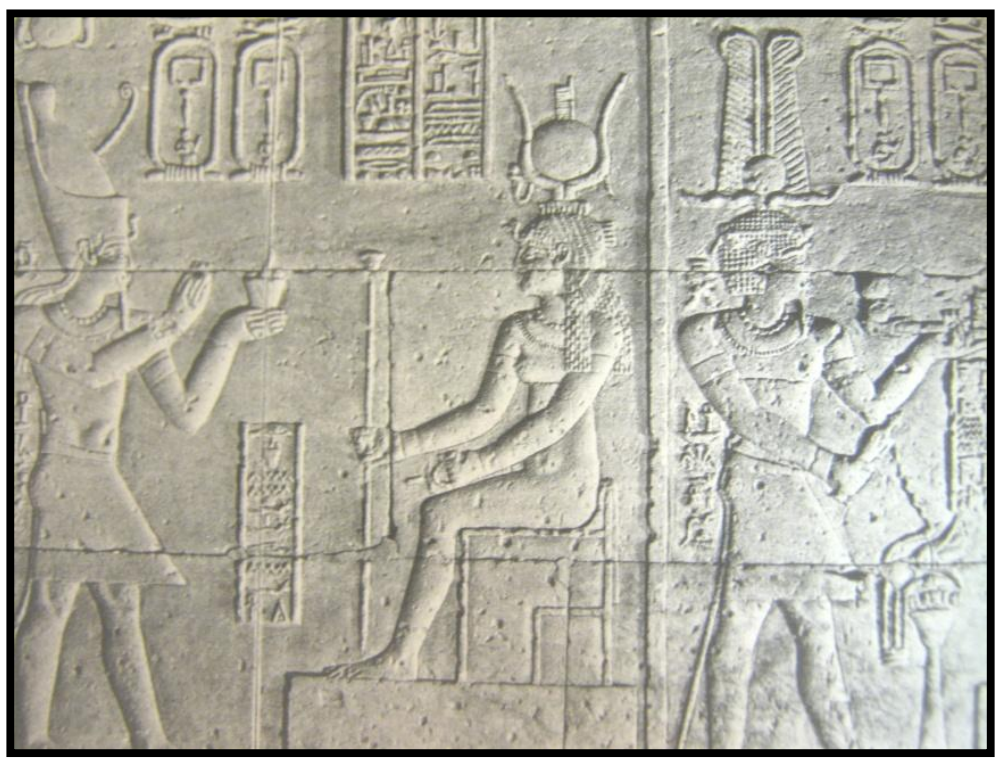

Fig. 9

Emperor Augustus presents offerings to Isis, Temple of Philae

Ref: Tram Tan Tinh, Les empereurs romains versus Isis, Serapis, Fig. 1. 


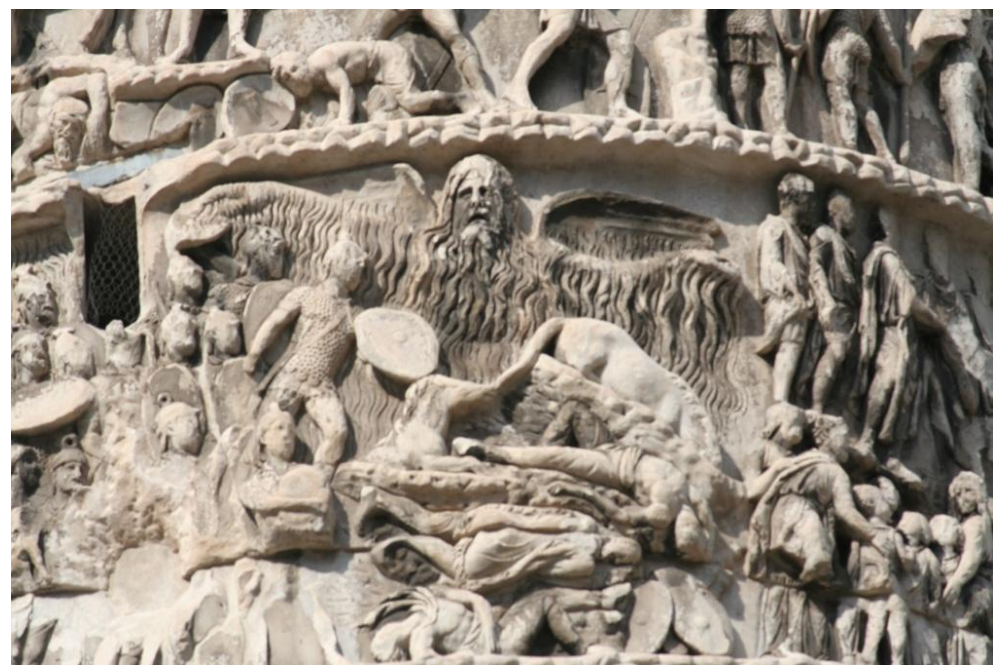

Fig. 10

\section{Rain miracle, column of Marcus Aurelius, Rome}

Ref: Martin Beckmann, The Column of Marcus Aurelius, (U.S.A, 2011)
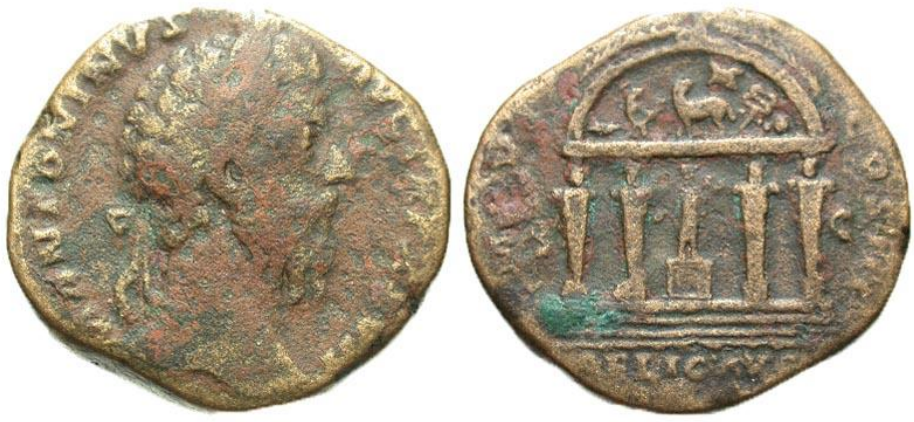

Fig. 11

Coin of Marcus Aurelius, British Museum Coins No. 1441

Ref: BMC IV, No 1441. 
${ }^{1}$ Previous studies: Essien Okon, "Religion and politics in ancient Egypt", AJSMS 3 (2012), 93-98. It talked about the Pharaonic period till the old Kingdom and mentioned only the change of the state god.

Heather Wellendrof, "Ptolemy's Political tool: Religion", Studia Antiqua 6.1 (2008), 33-38. It mentioned only the role played by Ptolemy I in inventing Serapis and respecting the Egyptian gods.

${ }^{2}$ Toby Wilkinson, Early Dynastic Egypt, (London, 1999).

${ }^{3}$ E. Kohler and E. Van den Brink, "Four Jars with Incised Serekh-signs from Helwan recently retrieved from the Cairo Museum”, GM 187 (2002), 59-81.

${ }^{4}$ Elizabeth Wilson, The cult of Re in the Old Kingdom, (Sydney, 2002), 4-5.

${ }^{5}$ Francoise Dunand, Gods and Men in Egypt: 3000 BC to 395 CE, (Ithaca, 2004), 347.

${ }^{6}$ Jan Assmann, The Search for God in Ancient Egypt, (Ithaca \& London, 2001), 189 ff.

${ }^{7}$ Verlag Von Zabern, Official catalogue of the Egyptian Museum Cairo,( Mainz, 1987), No. 31.

8 James Henry Breasted, Ancient Records of Egypt, Vol. 2, (Chicago, 1906), 140.

${ }^{9}$ Kurth Sethe, "Urkunden der 18 Dynasty", In: Urk. 4, Volume 19 (1957); K. Fitzgerald, The Dream Stela Project, (University of Texas, 2010).

${ }^{10}$ Verena M. Lepper: "Untersuchungen zu pWestcar. Eine philologische und literaturwissenschaftliche (Neu-Analyse", In: $\ddot{A} A$, Band 70 (2008), 41-47, 103 \& 308-310.

${ }^{11}$ Ludwig Borchardt, Agyptische Tempel mit Umgang. Beitrage zur agyptischen Bauforschung und Altertumskunde, Heft 2, (Cairo, 1938), 209-215.

${ }^{12}$ Catherine Roehrig et ali, Hatshepsut: from queen to pharaoh, The Metropolitan Museum of fine art, (New York, 2005), 149.

13 David O'Connor and Eric Cline, Amenhotep III: Perspectives on his reign, the University of Michigan, (2001), 4.

${ }^{14}$ Labib Habachi, "Features of the deification of Ramses II", ADAIK 5, (1969).

${ }^{15}$ Charlotte Booth, The Hyksos Period in Egypt, (Malta, 2005), 29 - 31.

${ }^{16}$ Herodotus, Histoire, 3.37.

${ }^{17}$ Alan Fildes and Joann fletcher, Alexander the Great: son of the gods, (Los Angeles, 2004), 54.

${ }^{18}$ Ana Swiderek, "Serapis et les hellenomemphites", Hommages à Claire Preaux, (Brussels, 1975), 674.

${ }^{19}$ R. Giveon, "Tehne”, In: $L \ddot{A} 4$, Col. 304-305.

${ }^{20}$ G. Wagner, "Nouvelle inscriptions d'Akoris”, In: Hommages à Serge Sauneron 2, (IFAO, 1979), 51-55.

${ }^{21}$ Herodotus, Histories, II.50, II.52

${ }^{22}$ Anaxandrides was an Athenian Middle Comic poet. He wrote 65 plays, among them is the play named "The Cities".

${ }^{23}$ John Edmonds, The fragments of Attic Comedy, Volume 2, (Leiden, 1959), 61-62.

${ }^{24}$ Alain Charron A., La mort n'est pas une fine. Pratiques funeraires en Egypte d'Alexandre a Cleopatra, (Arles, 2002), 173

${ }^{25}$ Wallis Budge, the gods of the Egyptians, (New York, 1969), 176

${ }^{26}$ Charron, La mort n'est pas une fine, 173

${ }^{27}$ Charron, La mort n'est pas une fine, 175

${ }^{28}$ Gunter Hölbl, Geschichte des Ptolemäerreiches : Politik, Ideologie und religiöse Kultur von Alexander dem Großen bis zur römischen Eroberung, (Darmstadt, 1994), 77, Abb.6

${ }^{29}$ Robert Mond, Bucheum Vol. 2: the inscriptions, (London, 1934), 4, Pl. XL.

${ }^{30}$ Charron, La mort n'est pas une fine, 175

${ }^{31}$ Klaus Parlasca, Mumienportraits und verwandte Denkmäler, (Wiesbaden, 1966), 35 ; Roger Bagnall and D. Rathbone, Egypt from Alexander to Early Christians, (London, 2004), 128.

32 Francoise Dunand, Les grandes figures religieuses, Colloque de Besancon, (Paris, 1986), 63.

${ }_{33}$ Etienne Bernand, Recueil des inscriptions grecques du Fayoum, Tome 1, (Leiden, 1975), 40, No. 12.

${ }^{34}$ Etienne Bernand, Recueil des inscriptions grecques du Fayoum, 131, No. 70.

${ }^{35}$ Elizabeth Visser, Götter und Kulte im Ptolemaischen Alexandrien, (Amsterdam, 1983), $5 \mathrm{ff}$.

${ }^{36}$ Ellis Walter, Ptolemy of Egypt, (London, 1994), 60.

${ }^{37}$ Clarysse Willy, "Dynastic cults, Egypt”, In: Roger Bagnall, ed., The Encyclopaedia of ancient history, 2012 ; Henri Melaerts, "Le culte du souverain dans l'Egypte ptolemaique au IIIe siècle avant notre ere", StudHell 34 (1998).

${ }^{38}$ Wallis Budge, "A History of Egypt from the end of the Neolithic period to the death of Cleopatra VII 30 BC", Vol. VIII: Egypt under the Ptolemies and Cleopatra VII, Kegan Paul, Trench, Trubner \& Co.Ltd, 1902, 20.

${ }^{39}$ Robert Bianchi, "Cleopatra's Egypt: age of the Ptolemies", Brooklyn Museum, Detroit Institute of Arts, 1988, 35.

${ }^{40}$ Jacque Vandier J., Le papyrus Jumilhac, (Paris, 1961), 129 - 131, Col. XVII, line 14 - Col. XVIII, line 21. 
${ }^{41}$ J. Johnson, “The Role of the Egyptian priesthood in Ptolemaic Egypt", In: L. Lesko, ed., Egyptological Studies in honor of Richard Parker, ( London, 1986), 70 - 84.

${ }^{42}$ Wallis Budge, The Decrees of Memphis and Canopus, Vol. 3, (Virginia University, 1976).

${ }^{43}$ Serge Sauneron, The priests of Ancient Egypt, (New York, 1960), 57.

${ }^{44}$ Sherman Wallace, Taxation in Egypt from Augustus to Diocletian, (Oxford, 1937), 183-184.

45 A. Veisse, "Les revoltes egyptiennes, Recherches sur les troubles interieurs en Egypte du regne de ptolemee III a la Conquete romaine”, In: Studia Hellenistica 41, (2004), 98.

${ }^{46}$ Veisse, Les revoltes egyptiennes, 86.

${ }^{47}$ Porten Bezalel, The Elephantine Papyri in English: Three Millennia of cross-cultural continuity and Change, (Brill, 1996), $314-315$.

${ }^{48}$ Maurice Alliot, "La Thebaide en lute contre les rois d'Alexandrie sous Philopator et Epiphane (216 - 184)", In: $R B P h$ $29,(1951), 421-443$.

${ }^{49} \mathrm{M}$. Austin, The Hellenistic world from Alexander to the Roman Conquest: a selection of Ancient sources in translation, (Cambridge, 2006), 491 - 495.

${ }^{50}$ Wallis Budge, The Rosetta Stone, (New York, 1989), $51-66$.

${ }^{51}$ C. Preaux, "Esquisse d'une histoire des revolutions egyptienne sous les Lagides", CE 11, (1936), 532 - 537.

${ }_{53}^{52}$ Budge, The Rosetta Stone, $51-66$.

${ }^{53}$ Gunther Holbl, A history of Ptolemaic Empire, (New York, 2001), 156.

${ }_{55}^{54}$ P.Elph, n 15527 ; Veisse, Les 'Revoltes egyptiennes, 227.

${ }^{55}$ P. Teb.III, n 781 (164 BC).

${ }^{56}$ P. Teb. III, n 1699.

${ }^{57}$ P. Teb. I, 5.

${ }^{58} \mathrm{Holbl}$, A history of Ptolemaic Empire, $181 \mathrm{ff}$.

${ }^{59}$ P. Bouriant, 12.

${ }^{60}$ Preaux, "Esquisse d'une histoire des revolutions egyptienne", 549.

61 Virgil, Aeneid, Book 8, $698-700$.

${ }^{62}$ Gunther Hölbl, Altagypten im römischen Reich, der Römische Pharao und seine Temple I, (Mainz, 2000) ,40 ,Abb. 33

${ }^{63}$ Hölbl, Altagypten im römischen Reich, 113, Abb.155

${ }^{64}$ Description de l'Égypte : ou, Recueil des observations et des recherches qui ont été faites en Égypte pendant l'expédition de l'armée française, Vol. 1 ( Paris, 1809), Pl.82

${ }^{65}$ Geissen and Wolfram Weiser, Katalog Alexandrinischer Kaisermünzen der Sammlung des Instituts für Altertumskunde der Universität zu Köln, Band 1, (Opladen, 1983).

${ }_{67}^{66}$ Sharon Heyob, the cult of Isis among Women in the Graeco-roman World, EPRO, (Leiden, 1975), 22.

${ }^{67}$ Vincent Tram Tan Tinh, "Les empereurs romains versus Isis, Serapis", JRA Supl. 17, subject and Ruler: the cult of the ruling power in classical antiquity, (1996), 215.

${ }^{68}$ R. Witt, Isis in the Graeco-Roman world, (Britain, 1971), 97 ; A. Grimm, "Iside imperiale, aspetti storico-culturali del culto isiaco al tempo degli imperatori romani", in: A. Arslan, ed., Iside: il mito il mistro la magia, (Milano, 1997), 120.

${ }^{69}$ Tacitus, Annales, 2, 85, 4.

${ }^{70}$ Reinhold Merkelbach, Isis-Regina, Zeus Sarapis, die griechisch aegyptische religion nach den quellen dargestelle, (Leipzig, 1995), 133.

${ }^{71}$ Tram Tan Tinh, "Les empereurs romains versus Isis, Serapis", 218.

${ }^{72}$ M. Whittaker, "Jews and Christians: Graeco-Roman Views", In: A. Leaney, ed., the Jewish \& Christian World 200 BC to 200 AD, Vol. 6, (Cambridge, 1984), 113-114.

${ }_{74}$ Heyob, the cult of Isis, 27.

74 Tacitus, Historiae, 4.81.

${ }^{75}$ Barbara Levick, Vespasian, (London, 1999), 46 - 52.

${ }^{76}$ Orsolina Montevecchi, "Vespasiano acclamato dagli Alessandrini”, Aegyptus 61, (1981), 155 - 170.

${ }^{77}$ Suetonius, Vita divi Vespasiani, 7.1.

${ }^{78}$ Gary Beckmann, The Column of Marcus Aurelius: The Genesis and Meaning of a Roman imperial monument, (U.S.A, 2011).

${ }^{79}$ Dio Cassius, Augustae, 72.8 .4

${ }^{80}$ BMC IV, nos 611, 1441, 1443-1446.

${ }^{81}$ Routledge Alston, Soldier and Society in Roman Egypt: A social History, (New York, 2002), 77.

82 The Scriptores Historiae Augustae, Vol 1, Marcus Aure'lius Antoninus, 21, 25, 183-193. 
${ }^{83}$ Heyob, the cult of Isis, 32.

${ }^{84}$ Michel Malaise, Les conditions de penetration et de diffusion des cultes Egyptiens en Italie, EPRO 22, (Leiden, 1972), 450

${ }^{85}$ Stefan Pfeiffer, “The Imperial Cult in Egypt”, In: C. Riggs, ed., Oxford Handbook of Roman Egypt, (Oxford, 2012), 83 -100 .

${ }^{86}$ Philo, Legatio Ad Gaium, 149 - 151.

${ }^{87}$ Frederick Herklotz, Prinzeps und Pharao. Der kult des Augustus in Ägypten, Studien zur antiken Weltgeschichte 4, (Frankfurt, 2007), $273-275$.

${ }^{88}$ Jean Lauffray, "Abords occidentaux du premier pylone de Karnak: le dromos, la tribune et lea amenagements portuaires”, Kemi 21, (1971), 77-144.

${ }^{89}$ Malcolm Donalson, The cult of Isis in the Roman Empire. Isis Invicta, studies in classics, Vol. 22, (New York, 2003), 140-141.

${ }^{90}$ Flavius Josephus, Against Apion, Book 2, 73-74.

${ }^{91}$ Glenn Hinson, The church triumphant: A history of Christianity up to 1300, (U.S.A, 1995), $89-91$. 